\title{
Imagologické reflexie a hl'adanie podstaty literárneho diela
}

\author{
Anton Pokrivčák (Trnava)
}

\begin{abstract}
Abstrakt
Štúdia sa zamýšl'a nad podstatou významu literárneho diela prostredníctvom analýzy imagologického prístupu k štúdiu literatúry. Tento význam možno identifikovat' pomocou tzv. intrinzického prístupu, teda využívajúc terminológiu vlastnú literatúre ako takej alebo využitím terminologického aparátu iných vied. Literárna komparatistika mala odjakživa bližšie k mimoliterárnym javom, napríklad situujúc literatúru do národného, etnického alebo politického kontextu. V 20. storočí sa od nej oddelila imagológia, ktorej základným cielom nie je identifikácia estetickej hodnoty diela, ale mapovanie stereotypov prejavujúcich sa v mentálnych obrazoch svojho a cudzieho prostredníctvom literárneho diskurzu. Analyzujúc niektoré súčasné imagologické práce, autor poukazuje na fakt, že ich základným atribútom je práve odideologizovanie a subverzia takto vytvorených obrazov.
\end{abstract}

\section{Kl'účové slová}

literárna komparatistika; imagológia; mentálny obraz; stereotypy; extrinzický; intrinzický; národné; etnické

\section{Abstract \\ Imagological Reflections and the Search for the Essence of the Literary Work}

The study is a reflection on the essence of the meaning of a literary work through the analysis of imagological approach to the study of literature. The literary meaning can be identified by means of the so-called intrinsic approach, i.e. using terminology characteristic for literature as such, or via terminological apparatus of other disciplines. Comparative literature has always been closer to extraliterary phenomena, for example situating literature to national, ethnic or political contexts. In the $20^{\text {th }}$ century, it gave rise to imagology whose main aim is not to identify aesthetic value of the work, but to map stereotypes manifested in mental images of that which is my own and, on the other hand, the foreign, through literary discourse. Analysing some contemporary imagological works, the author points to the fact that their basic attribute lies in the de-ideologising and subversion of the created images.

\section{Key words}

comparative literature; imagology; mental image; stereotypes; extrinsic; intrinsic; national; ethnic 
Život a kultúra jednotlivých etnických komunít je v súčasnosti vel'kou témou svetovej literatúry, vychádzajúcou najmä z faktu, že mnohé tzv. národné literatúry sú v skutočnosti komplexom literatúr viacerých národnostných menšín tvoriacich jeden kultúrny celok. Je to tak nielen v Európe, kde národnostným a etnickým akcentom predchádzal vznik národných literatúr ako dôsledok najmä herderovských názorov zdôrazňujúcich prirodzené právo národov na svoju vlastnú národne orientovanú kultúrnu existenciu, ale aj v USA, kde sa koncept národa chápe ako politické súžitie nevyhnutne sprevádzané silnou demokratizáciou, v zmysle jednak popularizácie, ale aj politizácie kultúry, čo tvorí ideálny priestor pre zvýšené pertraktovanie etnického a ideologického v literatúre.

Tento trend sa nemohol vyhnút ani slovenskému literárnovednému kontextu. Vidíme to nielen na silnom zázemí komparatívneho skúmania (Ďurišin, ${ }^{1}$ Koprda, ${ }^{2}$ Gáfrik, Vajdová $^{3}$ ), ale aj v silnejúcom imagologickom diskurze, ktorého posledným príkladom je zbierka štúdii pod názvom Imagológia ako výskum obrazov kultúry: K reflexii etnických stereotypov krajin V4. ${ }^{4}$ Odborníka, ktorý sa orientuje v súčasnej literatúre a kultúre, ale aj politike, zvýšená intenzita výskumov na báze imagológie nemôže prekvapit, pretože súčasná doba je dobou hladania a boja o rôzne druhy identít, osobné, regionálne, národné, nadnárodné, etnické. Takéto snahy a hladania nachádzame zákonite aj v literárnej vede, a to aj vo viacerých iných prístupoch k štúdiu literatúry. Napríklad jedno z významných súčasných smerovaní v literárnej kritike (aj teórii) je postkoloniálny prístup, ktorý svoje tematické parametre situuje do protikladu Západ - Východ, s premietnutím na opozíciu kolonizovaní - kolonizátori, prostredníctvom ktorej porovnáva identity vychádzajúce z dvoch rozdielnych svetov, dvoch protichodných životných pocitov či pohladov na kultúrne alebo literárne artefakty. Komparácia identít sa tu využíva na zapojenie literatúry do širšieho spoločensko-politicko-ideologického spektra. Napriek prevládajúcemu jazyku hybridity, multikulturalizmu a globalizmu, postkoloniálne štúdiá sú v oblasti literatúry primárne determinované snahou o dosiahnutie určitej inštitucionalizovanej kultúrnej samostatnosti voči koloniálnym centrám na báze priestorovej a kultúrno-jazykovej, ale aj národnej a etnickej. Možno povedat, že literatúra tu slúži tomu, čomu slúžila v Európe v 19. storočí, ked' „literatúra a literárna veda nadobudli politické odôvodnenie, ako aj spoločenskú a akademickú prestiž tým, že sa stali strážcom národnej duše “5 .

1 Porov. ĎURIŠIN, Dionýz: Problémy literárnej komparatistiky. Bratislava: Vydavatel'stvo SAV, 1967; ĎURIŠIN, Dionýz: Teória literárnej komparatistiky. Bratislava: Slovenský spisovatel', 1975; ĎURIŠIN, Dionýz: Theory of Interliterary Process. Trans. Jessie Kocmanová and Zdenek Pistek. Bratislava: Slovak Academy of Sciences, 1989.

2 Porov. KOPRDA, Pavol: Medziliterárny proces VI. Teórie medziliterárnosti 20. storočia I. Nitra: Univerzita Konštantína Filozofa v Nitre, Filozofická fakulta, 2009; KOPRDA, Pavol, a kol.: Medziliterárny proces VII. Teórie medziliterárnosti 20. storočia II. Nitra: Univerzita Konštantína Filozofa v Nitre, Filozofická fakulta, 2010.

3 VAJDOVÁ, Libuša - GÁFRIK, Róbert (eds.): New Imagined Communities: Identity Making in Eastern and South-Eastern Europe. Bratislava: Kalligram, Ústav svetovej literatúry SAV, 2010.

4 ZELENKA, Miloš - TKÁČ-ZABÁKOVÁ, Lenka (eds.): Imagológia ako výskum obrazov kultúry: K reflexii etnických stereotypov krajin V4. Nitra: Univerzita Konštantína Filozofa v Nitre, 2018.

5 CORNIS-POPE, Marcel - NEUBAUER, John: History of the Literary Cultures of East-Central Europe. Junctures and Disjunctures in the $19^{\text {th }}$ and $20^{\text {th }}$ Centuries. Volume III: The Making and Remaking of Literary Institutions. Amsterdam/Philadelphia: John Benjamins Publishing Company, 2004; do SJ preložil A. P. 
Okrem národnej identity však literárna veda, najmä na Západe, skúma aj iné oblasti, ktorými sa ludia identifikujú voči svojmu okoliu. Do svojej Introducing Criticism at the 21st Century ${ }^{6}$ Julian Wolfreys napr. zarad’uje články autorov analyzujúcich diasporickú, rodovú a transrodovú identitu, ako aj identitu rasovú a feministickú. Prirodzene, otázky identity nie sú v literárnej vede 21. storočia pertraktované len takýmto priamym tematickým záberom, ale objavujú sa aj prostredníctvom iných diskurzov, ktoré významným spôsobom determinujú podložie súčasného života. Jedným z najsilnejších vplyvov na literárnu vedu je v tomto zmysle zvýšená digitalizácia súkromného a verejného priestoru, zasahujúca aj do výsostných sfér netechnologických humanitných vied. Tak napr. Ostrowicki ${ }^{7}$ charakterizuje elektronické prostredie ako sféru bytia, prisudzuje mu existenčný status. Otázka identity v prostredí tvorenom elektronickými javmi podla neho nadobúda úplne inú dimenziu ako všetko to, čo sme doteraz poznali.

Napriek všetkým uvedeným „novotám“, dominujúcim najmä v priestore na západ od nás, náš vlastný, stredoeurópsky priestor stále najvýraznejšie definuje svoju identitu prostredníctvom príslušnosti k jednotlivým národným a národnostným celkom. Príčinou sú v prvom rade dejiny dlhého a komplikovaného spolunažívania v tomto priestore a v neposlednom rade aj fakt, že Európska únia samotná je napriek svojej proklamovanej nadnárodnosti primárne spoločenstvom národných štátov. Národné štáty stoja aj na počiatku vzniku komparatívnej literatúry, ktorá je priestorom, z ktorého sa postupne vykryštalizovala komparatívna imagológia ako relatívne samostatná disciplína literárneho porovnávania. Presadzovanie sa konceptu národného v imaginácii Európanov sa však začalo už podstatne skôr, v romantickom stotožnení krásna a dobra s ludovým, ak odhliadneme od samozrejmého a nespochybnitel’ného faktu, že už „v antike patrilo porovnávanie textov $k$ bežnej praxi práce s textom “. ${ }^{8}$ Pospolitý l’ud ako nositel' národných atribútov v neskoršom období stratil svoju dôležitost’ na úkor abstraktnejších predstáv o národných hodnotách a vlastnostiach, národného charakteru, ktorý sa začal skúmat predovšetkým v spomínanej literárnej komparatistike. Nebudeme sa tu však venovat celým dejinám komparatívneho skúmania literatúry, ktoré sú príliš komplexné (prejavujúce sa prostredníctvom rôznych princípov porovnávania - od jednotlivých autorov, vplyvov, tém, cez koncept svetovej literatúry, na ktorého začiatku stál Goethe, pojem medziliterárnych spoločenstiev slovenského komparatistu Dionýza Ďurišina, univerzálnej, globálnej, či dokonca planetárnej literatúry ${ }^{9}$ etc.), ale skôr tej časti, ktorá výraznou mierou prispela k vzniku imagológie.

6 Porov. WOLFREYS, Julian: Introducing Criticism at the $21^{s t}$ Century. Edinburgh: Edinburgh University Press, 2002.

7 Porov. OSTROWICKI [AKA SIDEY MYOO], Michał: The Metaphysics of Electronic Being. In: CLCWeb: Comparative Literature and Culture 12. 3 (2010). Dostupné na internete: https://doi.org/10.7771/14814374.1530.

8 GÁFRIK, Róbert: Literárna komparatistika. In: Hyperlexikón literárnovedných pojmov. Ústav svetovej literatúry SAV. Dostupné na internete: http://hyperlexikon.sav.sk/sk/pojem/zobrazit///literarna-komparatistika.

9 Porov. ELIAS, Amy J. - MORARU, Christian: The Planetary Turn: Relationality and Geoaesthetics in the Twenty-First Century. Northwestern University Press, 2015. 
Pokial' porovnávanie (väčšinou národných) literatúr malo svoju už relatívne dlhú históriu, vznik imagológie môžeme podla Zelenku zasadit do konca „19. storočia po založeni katedier komparatistiky na francúzskych univerzitách “. ${ }^{10}$ Jej d’alší vývin možno ohraničit „prelomom 50.-60. rokov 20. storočia, ked’ politici Konrad Adenauer a Charles de Gaulle kládli symbolické základy európskej civilizácie, pre ktorú sa stalo klúčovým prekonanie tradičnej nemecko-francúzskej rivality, resp. jej presun z politicko-ideologickej roviny do sféry intelektuálneho diskurzu“. ${ }^{11}$ Tretiu etapu Zelenka vymedzuje začiatkom devätdesiatych rokov 20. storočia. Pokial prvá etapa bola charakteristická ešte klasickými počiatočnými sondami do rôznych metodologických oblastí skúmania literatúry, ktorá samotná ešte nebola plne vydelená ako samostatný akademický diskurz, druhá etapa bola z hladiska identifikácie imagologickej metódy klúčovou a vyhranila sa najmä v spore o tvár literárnej komparatistiky ako takej. Tento spor sa do povedomia odbornej verejnosti dostal najmä ako spor medzi Reném Wellekom, americkým komparatistom českého pôvodu, ktorý sa zúčastňoval aj na stretnutiach Pražského lingvistického krúžku a po emigrácii do USA sa považoval taktiež za jedného z tzv. Nových kritikov, a neskôr bol zakladatelom literárnej komparatistiky na americkej univerzite Yale, a tzv. francúzskou školou. Vzhladom na jeho zásadnost určite nebude preháňaním, ak povieme, že to bol nielen spor o metodológiu porovnávacieho skúmania literatúry, ale aj o podstatu literárnovedného skúmania vo všeobecnosti. Pokial Wellek v duchu svojho štrukturalistického poňatia literárneho bádania, ako aj podstaty literárneho diela vel'mi jasne proklamovanej v knihe Theory of Literature ${ }^{12}$ bol zástancom tzv. intrinzického prístupu, francúzski komparatisti vychádzali z extrinzického pohladu na literárnu vedu, t. j. nazerali na skúmanie literárneho diela prostredníctvom iných disciplín. Polemika bola ostrá a určite aj užitočná, aj ked’ pri spätnom pohlade možno povedat', že žiadna zo stránok sporu nemohla, alebo skôr nemala vyhrat', pretože len intenzívnejšie akcentovali jednu alebo druhú stránku komplexnosti literárneho procesu. Po rokoch na to Wellek spomína takto: „Predniesol som referát, „Kriza komparatínnej literatúry“, na kongrese v Chapel Hill, a tento referát bol všeobecne dezinterpretovaný ako útok na Francúzov. Namiesto toho to však bol polemický názor proti koncepcii komparatínej literatúry, ako ju propagovali odbornici na Sorbonne, Baldensperger, ktorý v tom čase už bol v USA, mladši l’udia ako Carré, Van Tieghem a Guyar. Môj referát bol zle pochopený. Bolo to len odmietnutie ich metodológie, ktorá bola obmedzená vo svojom dôraze na čisto externé vztahy, napriklad vplyv Goetheho. Francúzskym argumentom bolo, že jeho vplyv bol vel'ký vzhl'adom na nezvyčajne hlboké porozumenie Goetheho a Nemecka vo Francúzsku. "13

Zdá sa, že nasledujúci vývin teórie literatúry sa viac priklonil na stranu Francúzov a posunul tieto prirodzené metodologické kontroverzie do extrémnejších polôh, v ktorých jednej časti bola prisúdená pozícia spiatočníctva, reakcionárstva a tej druhej napr.

10 ZELENKA, Miloš: K teórii komparatistickej imagológie. In: ZELENKA, Miloš - TKÁČ-ZABÁKOVÁ, Lenka (eds.): Imagológia ako výskum obrazov kultúry: K reflexii etnických stereotypov krajín V4. Nitra: Univerzita Konštantína Filozofa v Nitre, 2018, s. 8.

11 Tamže, s. 9.

12 Porov. WELLEK, René - WARREN, Austin: Theory of Literature: A Seminal study of the nature and function of literature in all its contexts. Peregrine Books, 1963.

13 Porov. DEMETZ, Peter: Third Conversation with Rene Wellek. In: Cross Currents, 1992, 11(1992), s. 84. 
zásluhovosti za modernizáciu štúdia literatúry. Odhliadnuc napríklad od pochopitelnej ideologickej nevraživosti tzv. Nových lavičiarov v USA voči konzervativizmu Nových kritikov, je to viditelné aj v metodologických polemikách štrukturalistov a postštrukturalistov, ktoré boli a sú taktiež vypäté. Predstavitelia postštrukturalistického diskurzu zvaného „teória“ napr. považovali Nových kritikov za konzervatívnych akademikov neschopných vidiet' literatúru v širších súvislostiach a sústred’ujúcich sa len na úzky jazykový priestor literárneho diela. Na druhej strane René Wellek považoval nové postštrukturalistické prístupy k štúdiu literatúry za jej ohrozenie. ${ }^{14}$ Jeden zo zakladatel’ov „imagológie“, Hugo Dyserinck, si zase myslel, že René Wellek „už viac neprispel k stabilizácii alebo dokonca d’alšiemu rozšireniu alebo konsolidácii komparatívnej literatúry v Spojených štátoch alebo vo svete" ${ }^{15}$ ba dokonca, že jeho „vplyv na rozvoj komparatizmu bol skôr deštruktívny“. ${ }^{16}$ Dyserinck šiel ešte d’alej a považoval komparatívnu literatúru za disciplínu, ktorá nevyužila slubné možnosti na rozvoj takej literárnej vedy, ktorá by bola nezávislá a kultúrne neutrálna, „oslobodená od národných filologických väzieb, sformovaná z kombinácie medzinárodného porovnávania literatúr a výskumu medzinárodných literárnych a intelektuálnych vzt’ahov". ${ }^{17}$

Práve na troskách komparatívnej literatúry vznikla podla Dyserincka komparatívna imagológia, najmä zásluhou jeho aktivít, ako aj aktivít jeho spolupracovníkov na univerzite $\mathrm{v}$ Aachen, s vel'kým extraliterárnym príslubom. ${ }^{18}$ Extraliterárny prísl’ub je vlastne to, v čom spočíva podstata imagologického skúmania a prečo možno pochopit nechut štrukturalisticky orientovaných literárnych vedcov, pre ktorých je charakteristický texto-centristický pohlad na literárne dielo, považovat takýto prístup za relevantný smer pri analýze literárneho diela. Pre imagológiu (ako aj pre iné extrinzické prístupy) totiž hlavným ciel’om interpretácie nie je sústredenie sa na estetickú rovinu literárneho diela, generovanú komplexnostou jeho jazykových štruktúr, ale na to, čo nám dielo hovorí o mimoliterárnych javoch.

Mimoliterárne javy reflektované prostredníctvom literárnych diel sú v jadre záujmu autorov už spomenutej publikácie Imagológia ako výskum obrazov kultúry. Cielom autorov jednotlivých príspevkoch bolo poukázat na vznik a zobrazenie etnických stereotypov na základe obrazov iných (národov, národností, etnických a náboženských skupín) v niektorých majoritných alebo aj minoritných literatúrach stredoeurópskeho priestoru, teda v podstate na mimoliterárne javy reflektované, prípadne aj spoluvytvárané, umeleckými dielami. Takmer v žiadnej z jednotlivých štúdií nenachádzame analýzu diela alebo javu z hladiska jeho estetickej hodnoty, ale v prvom rade z hladiska jeho miesta vo vytváraní unikátneho kultúrno-historicko-politického kontextu. Miloš Zelenka, autor úvodnej štúdie situujúcej komparatívnu imagológiu do literárnovedného kontextu 20. storočia, poukazuje na túto jej dvojdomost', ked' hovorí, že „od 90. rokov 20. storočia až do súčasnosti sa

14 Porov. WELLEK, René: The Attack on Literature and Other Essays. The University of North Carolina Press, 1982.

15 DYSERINCK, Hugo: Imagology and the Problem of Ethnic Identity. In: Intercultural Studies, no. 1., 2003. Dostupné na internete: http://www.interculturalstudies.org/ICS1/Dyserinck.shtml, do SJ preložil AP.

16 Tamže, do SJ preložil A. P.

17 Tamže, do SJ preložil A. P.

18 Tamže. 
imagológia vyvíja dvoma smermi: smerom k literárnej vede a ku komparatívnemu štúdiu slovesných textov a smerom $k$ antropologickej analýze dejin mentalit ${ }^{.19}{ }^{19}$ Inými slovami by bolo možné povedat, že v podstate pokračuje v tom, čo bolo pre ňu charakteristické počas celého obdobia svojej existencie, v zasadzovaní literatúry do širšieho spoločenského kontextu, čím však nenadobúda „význam iba pre porovnávaciu literárnu vedu, ale aj pre iné oblasti, ako politika, sociológia, psychológia“. ${ }^{20}$ Vlastnost', ktorou sa však imagológia odlišuje od iných postštrukturalistických prístupov, je to, že k obrazom iného alebo cudzieho v literárnych diskurzoch nepristupuje s cielom fixovat tieto predstavy, ale ich relativizovat' (čo sa už nedá povedat’ o postkoloniálnych štúdiách, ktoré sú ideologické skrz-naskrz), „teda jej hlavný význam spočiva v prekonávani nacionalistických predstáv v spoločenských vedách o hodnotovej či estetickej nadradenosti niektorých národov".21

Ďalšie štúdie sú ako keby demonštráciou imagologickej metódy pri skúmaní rôznych javov stredoeurópskeho kultúrneho a politického priestoru. Tibor Žilka napríklad vo svojej štúdii Etnicita ako prostriedok stereotypizácie (literárnych postáv)²2 odkrýva stereotypné vykresl’ovanie postáv, na báze svoj - cudzí v slovenskej aj mad’arskej próze. V mnohých románoch totiž predstavitelia toho druhého národa boli väčšinou charakterizovaní negatívne, t. j. autori ich obdarili negatívnymi stereotypnými obrazmi kolujúcimi v kolektívnej predstavivosti svojho vlastného národa - Mad’ari ako satirické alebo kruté postavy, mad’arské ženy ako temperamentné až erotizujúce typy, prípadne Mad’ari ako predstavitelia moci v slovenských dielach ${ }^{23}$ a na druhej strane Slováci ako reprezentanti čistoty a neskazenosti l’udu, prípadne humorné, tragické alebo manipulované postavy. ${ }^{24}$ Na podobnú stereotypizáciu slovenských literárnych postáv poukazuje vo svojej štúdii aj Anna Zelenková prostredníctvom analýzy toposu drotára, teda zrejme jedného z najcharakteristickejších popularizujúcich obrazov slovenskosti v 19. storočí. ${ }^{25} \mathrm{~V}$ obidvoch prípadoch tieto obrazy obsahujú vel'kú mieru fiktívnosti, čím sa vlastne dostávame na výsostné teritórium imagologických snažení - k snahám o odideologizovanie takýchto „heteroimages“.

Odideologizovanie a subverzívnost̉ imagologického pertraktovania národných a národnostných stereotypov možno vel’mi účinne dosiahnut aj humorom, iróniou a satirou. Peter Káša v článku Aki sme Rusini? (Obrazy a stereotypy v tvorbe Štefana Suchého) prostredníctvom analýzy diela rusínskeho autora Štefana Suchého dospieva k zisteniu, „že osudom Rusinov bola kedysi d’aleká Amerika, neskôr bližšie Čechy a dnes stači už len Žilina 'za hum-

19 ZELENKA, Miloš: Op. cit., s. 11.

20 Tamže, s. 14.

21 Tamže, s. 12.

22 ŽILKA, Tibor: Etnicita ako prostriedok stereotypizácie (literárnych postáv). In: ZELENKA, Miloš - TKÁČ-ZABÁKOVÁ, Lenka (eds.): Imagológia ako výskum obrazov kultúry: K reflexii etnických stereotypov krajín V4. Nitra: Univerzita Konštantína Filozofa v Nitre, 2018, s. 17-27.

23 Tamže, s. 19.

24 Tamže, s. 23-24.

25 ZELENKOVÁ, Anna: K imagologickej reflexii toposu drotára v libretách J. K. Chmelenského a K. Želenského („obraz suseda" v česko-slovenských kultúrnych vzt’ahoch 19. storočia). In: ZELENKA, Miloš - TKÁČC-ZABÁKOVÁ, Lenka (eds.): Imagológia ako výskum obrazov kultúry: K reflexii etnických stereotypov krajín V4. Nitra: Univerzita Konštantína Filozofa v Nitre, 2018, s. 37-44. 
nami’ ako 'slovenský Jeruzalem “. ${ }^{26}$ Aj ked’ základným zámerom autora je tu identifikácia stereotypizácie „auto- a heteroimages“ tejto východoslovenskej etnickej skupiny (autor tu naráža na zvýšenú intenzitu vystahovalectva za prácou do USA v porovnaní s ostatnými slovenskými regiónmi, čo bolo zase spôsobené väčšou chudobou na východnom Slovensku, ako aj na historicky bližší vztah „východniarov“ v bývalom Československu k Prahe, než k Bratislave), nevyhýba sa ani náznakom estetického hodnotenia niektorých diel.

Velmi frekventovaným objektom stereotypizácie boli (v určitom zmysle aj stále sú) v stredoeurópskom priestore Židia, ktorým sa prisudzoval škodlivý vplyv na slovenský pospolitý l’ud. Ján Gallik v štúdii nazvanej Formovanie stereotypného pohl'adu na Židov v slovenskej tlači ${ }^{27}$ napríklad poukazuje na to, že Židom sa vyčítalo okrem tradičnej podpory alkoholizmu v dedinských krčmách a s tým spojenou úžerou aj nedostatok lojality k slovenskému národu, najmä v medzivojnovom období po vzniku Československej republiky, a prepojenie „židovstva s mad’arským živlom“.28 Gallik d’alej tvrdí, že práve „analýza vžitých predstáv o iných (kategorizácia etnických skupin) [nám môže] prostredníctvom umeleckého diskurzu prispiet' nielen $k$ identifikácii koreňov heterostereotypov, ale najmä k prekonávaniu negatívnych - ̌̌asto paušalizovaných - mentálnych obrazov v širšom spoločenskom povedomí, pretože je to dôležité nielen z hl'adiska prebiehajúcich stredoeurópskych integračných úsili a aktívneho pôsobenia proti predsudkom či etnickej diskriminácii, ale vôbec v uvedomeni si faktu, že pokial' sa nezahoji priepast medzi židmi, krestanmi a moslimami, tak neprekonáme beznádejné, mŕtve body egoistického l’udského myslenia a logiky“. ${ }^{29}$

Imagológia bezpochyby ponúka viac príkladov analýzy kultúrnych, politických, národných, národnostných alebo etnických javov nielen v problematických obdobiach, napr. v období tzv. Slovenského štátu, ale nachádzame v nej potenciál oslovit aj dnešok s jeho multikultúrnymi tendenciami. Tak napríklad Gabriella Petres Csizmadia pozerá na národnú identitu cez prizmu minulosti aj súčasnosti, prostredníctvom úzko regionálnych determinantov, ako aj z hladiska presahujúceho stredoeurópske hodnoty, napr. ked' v súvislosti s analyzovaným románom zdôrazňuje mnohorozmernost životného pocitu hlavnej hrdinky Petry, teda dievčiny „so slovenským pasom [ktorá] odpovedá na anglické otázky po mad'arsky“. ${ }^{30}$ Hlavným cielom, na ktorý sa Csizmadia snaží pravdepodobne poukázat, je fakt, že príslušnost̉ k určitému celku má nielen svoju pragmatickú stránku, ale je to aj otázka bytia, teda sebaidentifikácie na ontologickej báze.

Všetky uvedené príklady imagologických analýz sú určite ilustráciou mnohorozmernosti literárneho procesu, a teda aj komplexnosti významu literárneho diela. Aj ked'

26 KÁŠA, Peter: Aki sme Rusini? (Obrazy a stereotypy v tvorbe Štefana Suchého). In: ZELENKA, Miloš - TKÁČ-ZABÁKOVÁ, Lenka (eds.): Imagológia ako výskum obrazov kultúry: K reflexii etnických stereotypov krajín V4. Nitra: Univerzita Konštantína Filozofa v Nitre, 2018, s. 29-36.

27 GALLIK, Ján: Formovanie stereotypného pohladu na Židov v slovenskej tlači. In: ZELENKA, Miloš - TKÁČC-ZABÁKOVÁ, Lenka (eds.): Imagológia ako výskum obrazov kultúry: K reflexii etnických stereotypov krajín V4. Nitra: Univerzita Konštantína Filozofa v Nitre, 2018, s. 73-86.

28 Tamže, s. 76.

29 Tamže, s. 84-85.

30 CSIZMADIA, Gabriella Petres: Skúsenost cudzoty v románe Katariny Durica Milovat' po slovensky. In: ZELENKA, Miloš - TKÁČCZABÁKOVÁ, Lenka (eds.): Imagológia ako výskum obrazov kultúry: K reflexii etnických stereotypov krajín V4. Nitra: Univerzita Konštantína Filozofa v Nitre, 2018, s. 67. 
ideologická a politická angažovanost̉ v literatúre bola a je často na úkor jej estetickej hodnoty, nemožno ju a priori odmietat’, pretože okrem potenciálneho podriadenia národnému alebo etnickému princípu je v nej aj rozmer ukotvenia v realite životnej situácie, pragmatickosti a pravdy, ktorý v univerzalistickej estetike velakrát chýba. Literárna veda si nemôže dovolit ignorovat tento pragmatický rozmer, pretože je mierou jej relevantnosti a kultúrotvornej funkcie. Akákolvek krajina pozostávajúca z rôznorodých etnických komunít nemôže nemat’ „multietnickú“ literatúru a nereflektovat na emancipačné impulzy týchto menších zložiek väčšieho kultúrneho celku. Napriek tomu je však potrebné zdôraznit aj to, že ak tento, povedané s Wellekom, extrinzický kontext v literárnej vede hypertrofuje, dostávame sa do situácie, ked' literatúra je skutočne ohrozená ideologickým didakticizmom. Nie je to však nevyhnutne prípad všetkých imagologických interpretácíi. Najmä ak ich autori nevychádzajú z dopredu definovaných stanovísk, ako sa to deje napríklad v súčasnej silne ideologizujúcej západnej literárnej vede, ale snažia sa skôr naplnit tú podstatnejšiu charakteristiku imagologického skúmania, t. j. jej relativizujúci impulz smerujúci k subverzii ideológie (vrátane tej estetickej, na ktorú svojho času upozornil Paul de $\mathrm{Man}^{31}$ ) a k naplneniu určitých univerzálnych ambícií literatúry.*

prof. PhDr. Anton Pokrivčák, PhD.

Katedra anglického jazyka a literatúry

Pedagogická fakulta, Trnavská univerzita v Trnave

Priemyselná 4, 91843 Trnava, Slovensko

anton.pokrivcak@truni.sk

31 Porov. DE MAN, Paul: Aesthetic Ideology. University of Minnesota Press, 1996.

* Štúdia je súčastou riešenia projektu VEGA 1/0799/18 Národnej literatúry v epoche globalizácie (vznik a vývin americko-slovenskej literárnej a kultúrnej identity. 